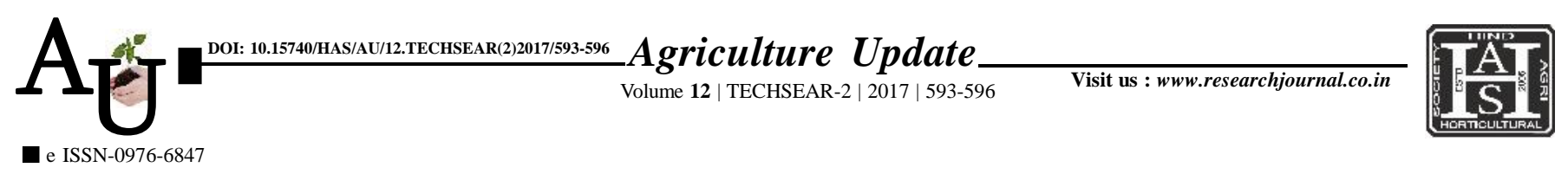

\title{
A Case Studx: Cisgenic approach for crop improvement and its biosafety issues
}

\author{
M. S. DUDHARE, N.E. JAYEWAR AND P.V. JADHAV
}

ArTicle Chronicle: Received : 12.07.2017; Accepted : 25.07.2017

Key Words : Cisgenic approach, Crop improvement, Biosafety issues

Author for correspondence :

\section{S. DUDHARE}

Biotechnology Center, Vasantrao Naik College of Agricultural

Biotechnology, (Dr. P.D.A.U.) YAVATMAL (M.S.) INDIA

Email : mahendra_s_d@

yahoo.com

See end of the article for authors' affiliations

How to cite this article : Dudhare, M.S., Jayewar, N.E. and Jadhav, P.V. (2017). Cisgenic approach for crop improvement and its biosafety issues. Agric. Update, 12(TECHSEAR-2) : 593-596; DOI: 10.15740/HAS/AU/ 12.TECHSEAR(2)2017/593-596.

A new method of genetically engineered (GE) crop plants known as cisgenics. A cisgenic plant is a plant that has been genetically modified using genes and regulatory elements exclusively from plants to which it can be crossed by normal breeding (Schaart, 2004). Because of the similarity of the introduced genes to those of the host plant, such improvements may be complitted efficiently through intragenic modification, a new approach to genetic engineering that transforms plants with native genetic elements only.

\section{Intragenic modification as a new extension to plant breeding :}

The genetic complexity of most undesirable features complicates efforts to eliminate them systematically through traditional breeding. Furthermore, it is difficult to increased food quality without compromising yield. Many genes associated with the biosynthesis of toxins play an important role in the plant's physiology and cannot be simply knocked-out. The easiest route to carefully modifying the expression levels of specific genes is afforded by genetic engineering. A few large agricultural biotechnology companies established a nearmonopoly position on commercial applications, which were directed toward the permanent incorporation of bacterial, viral, and synthetic DNA into crops. Although the resulting varieties displayed high levels of herbicide tolerance and insect resistance, their release into the environment triggered widespread biosafety and ethics concerns. In 2003, Kaare M. Nielsen (University of Troms, Norway) proposed to bridge the gap between agricultural biotechnology companies on one side and consumers and NGOs on the other by diversifying genetically engineered crops based on the genetic distance between DNA source and target crop (Nielsen, 2003). He defined organisms transformed with foreign DNA as transgenic, while using the term intragenic for plants containing native DNA. Intragenic modification isolates specific genetic elements from a plant, recombines them in vitro and inserts the resulting expression cassettes into a plant that belongs to the same sexual compatibility group using 